\title{
ANALISIS CAPAIAN BELAJAR SISWA SMAN DI INDONESIA TAHUN 2019 DENGAN PEMODELAN MIXED GEOGRAPHICALLY WEIGHTED REGRESSION
}

(Analysis of Learning Achievements in Indonesia High School Students in 2019 with Mixed Geographically Weighted Regression Modelling)

\section{Febrianto Nainggolan', Ernawati Pasaribu²}

Politeknik Statistika STIS ${ }^{1}$

Politeknik Statistika STIS 2

Jalan Otto Iskandardinata No. 64c, Jatinegara, Kota Jakarta Timur, DKI Jakarta 13330

E-mail: 16.9132@stis.ac.id

\begin{abstract}
ABSTRAK
Capaian belajar siswa secara nasional selama ini diukur dengan hasil Ujian Nasional (UN). Sebaran nilai UN siswa SMAN di Indonesia cenderung tidak merata, dimana capaian belajar yang tinggi hanya berada di pulau Jawa. Ironisnya, wilayah di Kawasan Timur Indonesia memiliki rata-rata nilai UN yang sangat rendah. Hal ini menarik bahwa wilayah dengan kategori nilai yang sama cenderung berdekatan dan mengindikasikan terdapat efek kewilayahan pada capaian belajar di Indonesia. Penelitian ini menganalisis karakteristik dan faktor-fakor yang memengaruhi capaian belajar siswa SMAN tingkat kabupaten/kota di Indonesia tahun 2019 dengan pendekatan model mixed Geographically Weighted Regression (mixed GWR). Hasil penelitian mendapatkan bahwa terdapat efek autokorelasi spasial dan heterogenitas spasial dalam pemodelan nilai UN SMAN tingkat kabupaten/kota dan faktor yang memengaruhinya di Indonesia pada tahun 2019. Analisis menggunakan model mixed GWR menghasilkan variabel kondisi bangunan ruang kelas, rasio siswa per kelas, dan nilai Uji Kompetensi Guru memengaruhi capaian belajar secara lokal di tiap kabupaten/kota. Sementara, PDRB per kapita berpengaruh secara global terhadap capaian belajar. Saran yang diberikan yaitu perbaikan bangunan ruang kelas, distribusi jumlah siswa per kelas dan sebaran guru berkemampuan tinggi yang lebih merata. Selain itu, perlu diadakan bentuk ujian yang lebih dapat menggambarkan kualitas pendidikan di Indonesia, sebagai pengganti Ujian Nasional.
\end{abstract}

Kata kunci: capaian belajar, Ujian Nasional, mixed GWR

\section{ABSTRACT}

National student learning outcomes have been measured by the results of National Examination (NE). The distribution of national exam scores for public high school (SMAN) students in Indonesia tends to be uneven, where high learning outcomes are only in Java. Ironically, regions in Eastern Indonesia have very low average NE scores. It is interesting that regions with the same value category tend to be close together and indicate that there is a regional effect on learning outcomes in Indonesia. This study analyzes characteristics and factors that affect learning outcomes of SMAN students at district/city level in Indonesia in 2019 using a mixed Geographically Weighted Regression (mixed GWR) model approach. The results of this study show that there is an effect of spatial autocorrelation and spatial heterogeneity in the modelling of SMAN National Examination scores at the districts/city level and the factors that influence it in Indonesia in 2019. Analysis using mixed GWR model produces variables of classroom building conditions, student per class ratio, and test scores. Teacher competency affect learning outcomes locally in each districts/city. Meanwhile, per capita GRDP has a global affect on learning outcomes. Suggestion are given, improving the classroom building, more even distribution of the number of students per class and distribution of highability teachers. In addition, it is necessary to hold a form of examination that can better describe the quality of education in Indonesia, as a substitute for the National Examination.

Keywords: learning outcomes, National Examinations, mixed GWR

\section{PENDAHULUAN}

Pendidikan merupakan salah satu aspek penting dalam pembangunan manusia. Pelaksanaan pendidikan berkualitas akan berdampak positif terhadap pembangunan sumber daya manusia yang berkualitas. Selain sebagai agenda ke-empat dalam Sustainable Development Goal's (SDG's) 
yang dicanangkan oleh Perserikatan Bangsa-Bangsa (PBB), pendidikan berkualitas juga merupakan tujuan pelaksanaan pendidikan nasional Indonesia (UU No. 20 tahun 2003).

Penilaian capaian belajar di Indonesia yang dilaksanakan melalui Ujian Nasional (UN) menggunakan standar yang ditetapkan secara nasional. Berdasarkan data Pusat Asesmen dan Pembelajaran Kementerian Pendidikan dan Kebudayaan (Kemdikbud), rata-rata hasil UN tingkat Sekolah Menengah Atas (SMA) dalam lima tahun terakhir tidak menunjukkan peningkatan yang signifikan. Selain itu sebaran nilai UN juga tidak merata antar wilayah. Mayoritas wilayah dengan capaian belajar yang tinggi hanya berada di pulau Jawa. Ironisnya, wilayah di Kawasan Timur Indonesia memiliki rata-rata nilai UN yang sangat rendah. Hal ini membuktikan pembangunan pendidikan di Indonesia masih terkonsentrasi di pulau Jawa. Fakta ini juga menegaskan bahwa kualitas pendidikan di Indonesia masih harus ditingkatkan. Selain itu, hal menarik dapat ditemukan bahwa wilayah kabupaten/kota dengan kategori nilai UN yang sama cenderung berlokasi berdekatan. Kondisi ini mengindikasikan terdapat efek kewilayahan pada capaian belajar di Indonesia.

Tujuan dari penelitian ini: pertama, untuk menjelaskan karakteristik capaian belajar siswa SMAN pada setiap kabupaten/kota; kedua, mendeteksi efek spasial pada sebaran capaian belajar siswa SMAN pada setiap kabupaten/kota; ketiga, menjelaskan analisis tentang karakteristik lokal yang memengaruhi capaian belajar siswa SMAN pada setiap kabupaten/kota di Indonesia tahun 2019. Metode analisis yang digunakan untuk menjawab ketiga tujuan penelitan adalah analisis deskriptif dengan peta tematik, uji autokorelasi dan heterogenitas spasial, serta analisis inferensia dengan pemodelan Mixed Geographically Weighted Regression (Mixed GWR).

\section{METODE}

\section{Konsep Capaian Belajar}

Capaian belajar merupakan hasil yang diharapkan diketahui, dipahami, dan dapat dikerjakan oleh peserta didik setelah menyelesaikan suatu periode belajar (Paradigma Capaian Pembelajaran, Kemenristekdikti). Definisi lain tentang capaian belajar yaitu menurut Winkel (1997) yang menyatakan capaian belajar adalah hasil yang diperoleh sebagai bukti kemampuan seorang siswa dalam melakukan kegiatan pembelajaran. Sementara, Chaplin (2002) menyatakan bahwa capaian belajar merupakan hasil yang telah dicapai dalam karya akademis yang dinilai oleh guru atau dosen melalui sebuah tes atau kombinasi dari beberapa tes. Azwar (2006) mengemukakan bahwa capaian belajar merupakan hasil maksimal seseorang dalam menguasai materi yang telah dipelajari. Dari beberapa definisi tersebut, dapat dinyatakan bahwa capaian belajar adalah hasil yang diperoleh melalui sebuah uji kemampuan sebagai bukti penguasaan materi pembelajaran.

Salah satu indikator capaian belajar di Indonesia adalah nilai UN yang merupakan ukuran kualitas capaian peserta didik pada tingkat pendidikan tertentu. UN dilaksanakan dengan menggunakan standar yang berlaku sama untuk semua peserta didik di semua wilayah. Standar pelaksanaan dan penilaian UN mengacu pada Standar Kompetensi Lulusan (SKL). Selanjutnya, hasil UN digunakan sebagai dasar untuk pemetaan mutu dan pembinaan satuan pendidikan (Permendikbud No. 43 Tahun 2019).

\section{Model Regresi Linier}

Regresi linier adalah metode analisis statistik statistik yang umum digunakan untuk menggambarkan hubungan antara satu atau lebih variabel bebas (variabel independen) dengan variabel tak bebas (variabel dependen) (Netter, Wasserman, dan Kutner, 1989). Secara umum, persamaan model regresi linier dinyatakan sebagai berikut:

$$
y_{i}=\beta_{0}+\sum_{k=1}^{p-1} \beta_{k} x_{i k}+\varepsilon_{i} ; i=1,2, \ldots, n ;
$$

\section{Keterangan:}

$y_{i} \quad$ : nilai variabel dependen pada pengamatan ke-i

$x_{i k} \quad$ : nilai variabel independen ke-k pada pengamatan ke-i

$\beta_{0} \quad$ : koefisien intercept (konstanta) 
$\beta_{k} \quad:$ koefisien slope (kemiringan)

$p-1 \quad$ : jumlah variabel independen

$\varepsilon_{i} \quad$ : random error ke-i diasumsikan berdistribusi berdistribusi $N\left(0, \sigma^{2}\right)$.

\section{Geographically Weighted Regression (GWR)}

Geographically Weighted Regression (GWR) adalah model regresi yang menghasilkan penduga parameter di semua lokasi penelitian (Fotheringham, Brunsdon, dan Charlton, 2002). Model GWR merupakan pengembangan regresi linier klasik untuk mengatasi masalah heterogenitas spasial. Model GWR tidak mengasumsikan hubungan antar variabel independen dan variabel dependen konstan (tetap) di seluruh wilayah. Model GWR mengidentifikasikan terjadinya variasi secara geografis (variasi spasial) pada hubungan antara variabel independen dan variabel dependen. Variasi spasial menunjukkan bahwa perubahan pada variabel independen menyebabkan perubahan yang berbeda pada variabel dependen di wilayah yang berbeda. Dengan kata lain, GWR mampu menghasilkan estimasi parameter untuk setiap titik lokasi (wilayah) yang diteliti. Model GWR dapat dituliskan sebagai berikut:

$$
y_{i}=\beta_{0}\left(u_{i}, v_{i}\right)+\sum_{k=1}^{p-1} \beta_{k}\left(u_{i}, v_{i}\right) x_{i k}+\varepsilon_{i}, i=1,2, \ldots, n ; .
$$

Keterangan:

$\begin{array}{ll}y_{i} & : \text { nilai variabel dependen pada wilayah ke-i } \\ x_{i k} & : \text { nilai variabel independen ke-k pada wilayah ke-i } \\ \left(u_{i}, v_{i}\right) & : \text { titik koordinat lokasi wilayah ke-i } \\ \beta_{0}\left(u_{i}, v_{i}\right) & : \text { konstanta (intercept) pada wilayah ke-i } \\ \beta_{k}\left(u_{i}, v_{i}\right) & \text { : parameter variabel independen ke-k pada wilayah ke-i } \\ p-1 & : \text { jumlah variabel independen } \\ \varepsilon_{i} & : \text { random error yang diasumsikan berdistribusi } N\left(0, \sigma^{2}\right)\end{array}$

\section{Mixed Geographically Weighted Regression (Mixed GWR)}

Pada model GWR, penduga parameter yang dihasilkan di semua lokasi memiliki koefisien yang berbeda-beda. Hal ini disebabkan pemodelan GWR mengasumsikan semua koefisien regresi dalam model bervariasi secara geografis. Pada kenyataannya tidak pasti semua koefisien variabel akan bervariasi secara geografis, variabel itu disebut sebagai variabel global. Variabel global merupakan variabel yang memiliki pengaruh konstan atau tidak bervariasi di semua wilayah observasi. Untuk mengakomodasi adanya variabel global dan lokal dalam satu model, maka digunakan model mixed GWR sebagai pengembangan dari model GWR (Fortheringham, Brunsdon, dan Charlton, 2002). Model mixed GWR diformulasikan sebagai berikut:

$$
y_{i}=\sum_{j=1}^{k_{a}} a_{j} x_{i j}+\sum_{l=1}^{k_{b}} b_{l}\left(u_{i}, v_{i}\right) x_{i l}+\varepsilon_{i}, i=1,2, \ldots, n ;
$$

Keterangan:

$\begin{array}{ll}y_{i} & : \text { nilai variabel dependen pada wilayah ke-i } \\ x_{i j} & : \text { nilai variabel independen ke-j pada wilayah ke-i } \\ x_{i l} & : \text { nilai variabel independen ke-l pada wilayah ke-i } \\ \left(u_{i}, v_{i}\right) & : \text { titik koordinat lokasi wilayah ke-i } \\ a_{j} & : \text { parameter variabel independen global ke-j } \\ k_{a} & : \text { jumlah variabel independen global } \\ b_{l}\left(u_{i}, v_{i}\right) & : \text { parameter variabel independen lokal ke-/pada wilayah ke-i } \\ k_{b} & : \text { jumlah variabel independen lokal } \\ \varepsilon_{i} & : \text { random error yang diasumsikan berdistribusi } N\left(0, \sigma^{2}\right)\end{array}$

\section{Sumber Data}

Data yang digunakan dalam penelitian ini merupakan data sekunder cross-section pada tahun 2019. Unit analisis penelitian ini adalah 514 kabupaten/kota di Indonesia. Data diperoleh dari beberapa sumber sebagai berikut: 
1. Statistik Umum Rapor Ujian Nasional tahun ajaran 2018/2019 Kemdikbud untuk mendapat variabel rata-rata nilai UN SMAN tiap kabupaten/kota.

2. Publikasi Neraca Pendidikan Daerah tahun 2019 Kemdikbud untuk mendapat variabel persentase kelas rusak, rasio siswa per kelas, dan nilai Uji Kompetensi Guru (UKG).

3. Publikasi Statistik Provinsi Dalam Angka tahun 2020 untuk mendapat variabel PDRB per kapita tiap kabupaten/kota.

\section{Tahapan Analisis}

Tahapan analisis pertama dilakukan menggunakan peta tematik untuk melihat gambaran capaian belajar. Selanjutnya dilakukan analisis inferensia dengan tahapan sebagai berikut:

1. Membentuk model regresi linier dengan metode OLS

2. Melakukan uji asumsi regresi linier

3. Melakukan uji efek autokorelasi spasial.

4. Melakukan uji efek heterogenitas spasial.

5. Menentukan bandwidth optimum dan fungsi kernel pembobot.

6. Membentuk model GWR.

7. Menguji variasi koefisien lokal GWR.

8. Jika terdapat koefisien yang tidak bervariasi, dilanjutkan dengan membentuk model mixed GWR.

9. Memilih model terbaik dengan pengujian goodness of fit untuk melihat apakah terdapat perbedaan yang signifikan antara model regresi global, GWR, dan mixed GWR.

10. Menguji signifikansi koefisien parameter lokal model terpilih.

11. Mengelompokkan wilayah kabupaten/kota menurut variabel yang signifikan dengan model terpilih.

\section{HASIL DAN PEMBAHASAN}

\section{Gambaran Umum Capaian Belajar}

Sebaran rata-rata nilai UN pada gambar 1 menunjukkan capaian belajar siswa SMAN pada tahun 2019 yang tidak merata di Indonesia pada tingkat kabupaten/kota. Hampir semua kabupaten/kota yang termasuk kategori sangat tinggi berada di Pulau Jawa. Ditinjau dari kewilayahan, mayoritas wilayah kabupaten/kota di kawasan barat Indonesia memiliki nilai dengan kategori nilai yang lebih tinggi daripada kabupaten/kota di kawasan timur Indonesia.

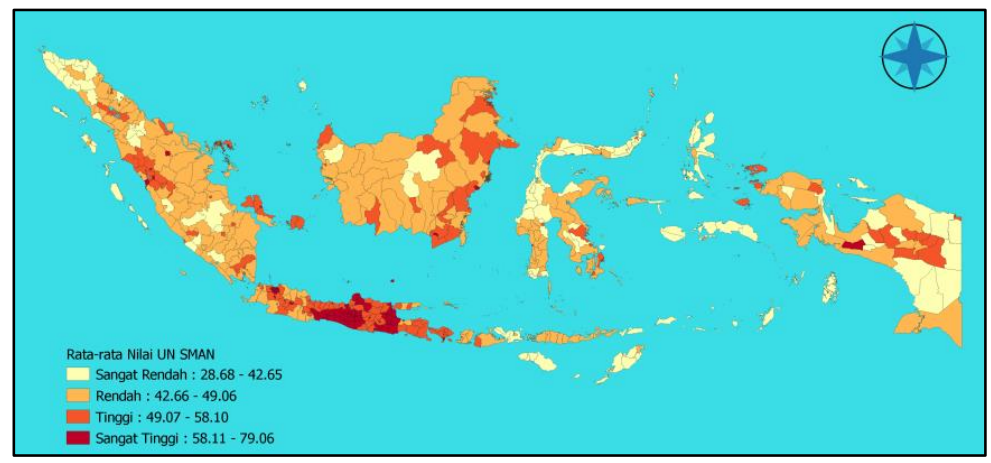

Gambar 1. Peta persebaran rata-rata nilai UN SMAN tingkat kabupaten/kota di Indonesia, Tahun 2019.

Melalui gambar 1 dapat diamati bahwa masih terdapat sebaran nilai yang beragam di berbagai wilayah di Indonesia. Hal ini mengindikasikan terdapat efek heterogenitas spasial pada persebaran capaian belajar siswa SMAN di Indonesia. Selanjutnya, disajikan gambar 2 berupa peta tematik variabel-variabel yang diduga berpengaruh terhadap capaian belajar. 


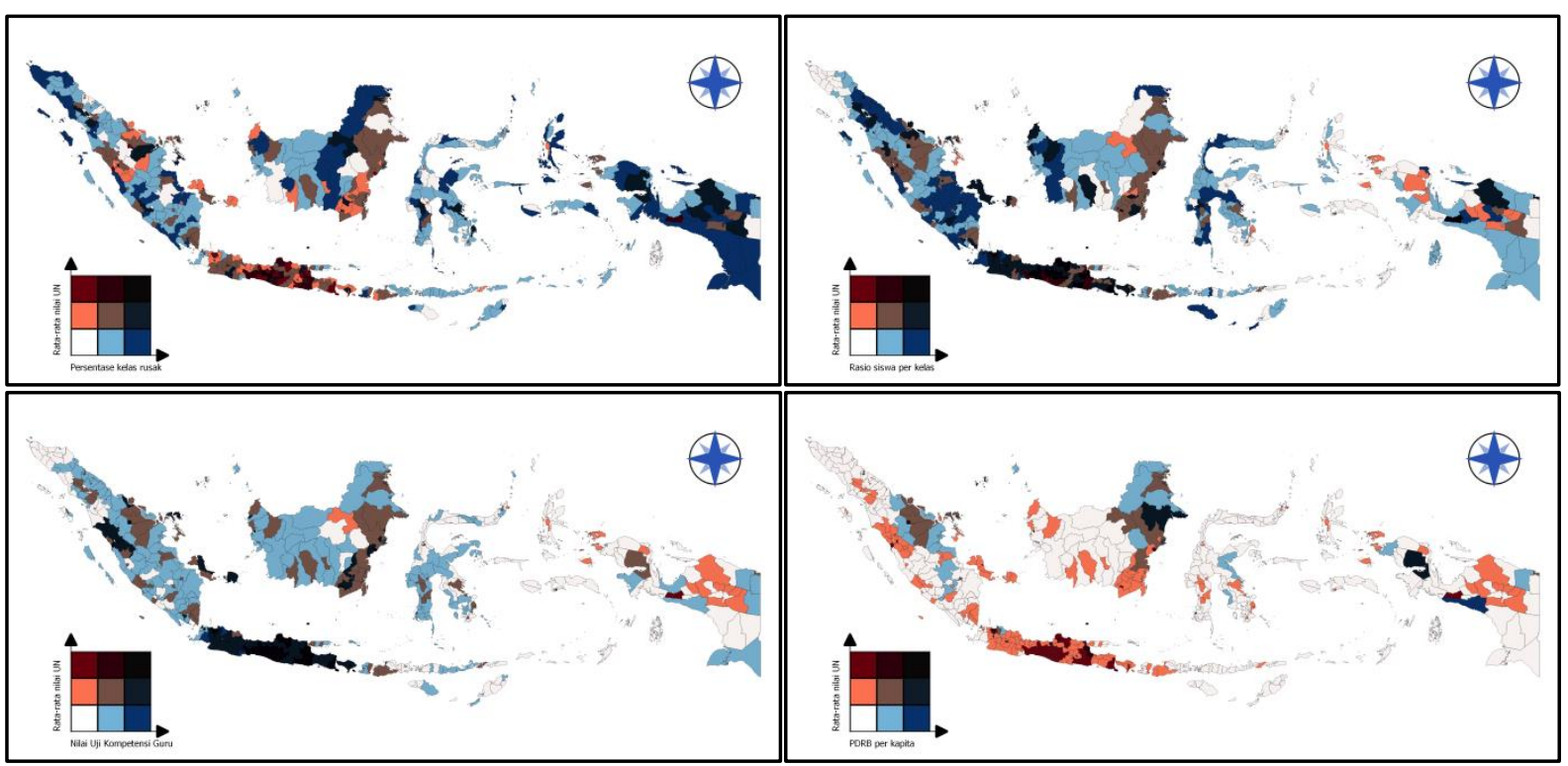

Gambar 2. Peta persebaran nilai rata-rata UN dengan: persentase ruang kelas rusak (kiri atas), rasio siswa per kelas (kanan atas), nilai Uji Kompetensi Guru (kiri bawah), dan PDRB per kapita (kanan bawah) menurut kabupaten/kota di Indonesia, Tahun 2019.

Gambar 2 menunjukkan persebaran nilai rata-rata UN (gradasi merah) dengan masing-masing variabel yang diduga memengaruhinya (gradasi biru). Keempat variabel menunjukkan pola persebaran yang berbeda-beda dengan pola persebaran nilai UN SMAN pada tahun 2019. Gambar 2 mengindikasikan adanya hubungan positif antara nilai UN SMAN dan nilai UKG (kiri bawah). Sedangkan, terdapat indikasi hubungan negatif antara nilai UN SMAN dengan persentase ruang kelas rusak (kiri atas) dan rasio siswa per kelas (kanan atas). Sementara, arah hubungan nilai UN dan PDRB per kapita (kanan bawah) belum dapat diidentifikasikan melalui gambar.

\section{Pembentukan Model Regresi Linier}

Pembentukan model regresi linier digunakan untuk melihat pengaruh variabel-variabel independen terhadap variabel dependen di semua wilayah dalam satu model persamaan. Persamaan regresi linier yang terbentuk adalah sebagai berikut:

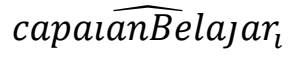

$$
\begin{aligned}
& =7,815658-0,027846(\text { RuangKelasRusak })_{i}{ }^{*}-0,320013(\text { RasioSiswaKelas })_{i}{ }^{*} \\
& +0,859813(\text { NilaiUKG })_{i}{ }^{*}+0,015647(\text { PDRBperkapita })_{i}{ }^{*}
\end{aligned}
$$

Berdasarkan persamaan yang terbentuk, variabel persentase ruang kelas dengan kondisi rusak, rasio siswa per kelas, nilai uji kompetensi guru, dan PDRB per kapita berpengaruh signifikan terhadap capaian belajar.

Selanjutnya, dilakukan pengujian asumsi model regresi linier yaitu asumsi normalitas, nonmultikolinearitas, non-autokorelasi, dan homoskedastisitas. Berdasarkan hasil pengujian asumsiasumsi, didapatkan bahwa terdapat pelanggaran asumsi normalitas, non-autokorelasi, dan homoskedastisitas. Meskipun begitu, residual model regresi linier tetap dapat dinyatakan berdistribusi normal karena memiliki jumlah sampel yang sangat besar dibandingkan jumlah parameter model (Freedman, 2009). Sementara, dengan adanya pelanggaran asumsi nonautokorelasi dan homoskedastisitas mengindikasikan adanya efek spasial pada nilai UN SMAN di Indonesia. Sehingga, perlu dilakukan pengujian efek spasial pada model regresi yang terbentuk.

Pengujian efek spasial pertama diakukan menggunakan statistik Moran's I atau Indeks Moran's untuk mengidentifikasi efek autokorelasi spasial. Pengujian Indeks Moran's dengan pembobot spasial jarak Gaussian menghasilkan angka Indeks Moran's yang signifikan ( $p$-value $=$ 0,0050 ) sebesar 0,5119. Berdasarkan hasil yang diperoleh, menyatakan bahwa terdapat efek autokorelasi spasial yang positif sehingga wilayah dengan jarak geografis yang berdekatan cenderung memiliki karakteristik yang sama. Selanjutnya, pengujian heterogenitas spasial 
menggunakan uji statistik Breusch-Pagan dengan derajat bebas 4 menunjukkan hasil yang signifikan ( $p$-value $<0,0001)$. Sehingga, dapat disimpulkan bahwa terdapat heterogenitas spasial pada model yang terbentuk.

Dengan adanya efek autokorelasi spasial dan heterogenitas spasial menujukkan bahwa nilai UN SMAN di Indonesia mengelompok secara bervariasi berdasarkan keunikan karakteristik pada setiap wilayah. Efek spasial yang muncul pada wilayah kabupaten/kota di Indonesia menunjukkan bahwa model regresi linier yang bersifat global kurang sesuai digunakan untuk melakukan analisis karena akan menghasilkan kesimpulan yang tidak tepat. Untuk melihat perbedaan pengaruh dari variabel independen terhadap variabel dependen antar wilayah, maka digunakan metode estimasi yang dapat mengakomodasi efek autokorelasi spasial dan heterogenitas spasial, yaitu metode Geographically Weighted Regression (GWR) (Fotheringham, Brunsdon, dan Charlton, 2002).

\section{Model Geographically Weighted Regression (GWR)}

Pembentukan model GWR menggunakan fungsi kernel fixed Gaussian menghasilkan koefisien yang berbeda-beda untuk masing-masing wilayah. Tabel 1 menunjukkan interval koefisien persamaan model GWR yang terbentuk.

Tabel 28. Interval koefisien persamaan GWR.

\begin{tabular}{ccc}
\hline Variabel & \multicolumn{2}{c}{ Interval koefisien GWR } \\
\cline { 2 - 3 } & Minimum & Maksimum \\
\hline Intercept & $-27,6085$ & 82,3569 \\
Persentase ruang kelas rusak & $-0,0843$ & 0,0546 \\
Rasio siswa per kelas & $-0,9397$ & 0,3937 \\
Nilai Uji Kompetensi Guru & $-0,4557$ & 1,5020 \\
PDRB per kapita & $-0,0089$ & 0,0693 \\
\hline
\end{tabular}

Selanjutnya, dilakukan pengujian terhadap variasi koefisien variabel independen di masingmasing wilayah (koefisien lokal). Hasil pengujian variasi ditampilkan pada tabel 2 berikut.

Tabel 2. Output pengujian variasi koefisien lokal.

\begin{tabular}{ccccc}
\hline Variabel & F-statistics & \multicolumn{2}{c}{ DOF for F test } & DIFF of Criterion \\
\hline Intercept & 50,1957 & 8,632 & 464,832 & $-317,6799$ \\
Persentase ruang kelas rusak & 3,6494 & 9,955 & 464,832 & $-14,6890$ \\
Rasio siswa per kelas & 43,5006 & 9,026 & 464,832 & $-292,9281$ \\
Nilai Uji Kompetensi Guru & 88,4379 & 7,204 & 464,832 & $-426,1887$ \\
PDRB per kapita & 1,7994 & 6,004 & 464,832 & 2,7817 \\
\hline
\end{tabular}

Nilai negatif difference of criterion (DIFF of Criterion) pada tabel 2 menunjukkan koefisien suatu variabel indepneden secara signifikan bersifat lokal atau bervariasi pada masing-masing wilayah kabupaten/kota. Nilai ini ditunjukkan oleh variabel persentase ruang kelas rusak, rasio siswa per kelas, dan nilai Uji Kompetensi Guru. Sedangkan, nilai positif menunjukkan bahwa tidak terdapat variasi secara spasial pada koefisien variabel independen, yaitu variabel PDRB per kapita. Dikarenakan tidak semua koefisien variabel bersifat lokal, maka dibutuhkan model yang dapat mengakomodasi perbedaan variasi antar variabel independen dalam memengaruhi variabel dependen, yaitu model mixed Geographically Weighted Regression (mixed GWR).

\section{Model Mixed Geographically Weighted Regression (Mixed GWR)}

Model mixed GWR digunakan untuk mengakomodasi variabel PDRB per kapita yang memiliki koefisien tidak bervariasi dengan menjadikan variabel tersebut sebagai variabel global. Variabel global memiliki besaran pengaruh yang sama atau konstan untuk semua wilayah observasi. 
Meskipun tidak bervariasi secara geografis, variabel PDRB per kapita tetap berpengaruh signifikan $(p$-value $<0,05)$ terhadap capaian belajar dengan nilai koefisien 0,0164 .

Sementara, variabel independen lain yang memiliki koefisien bervariasi digunakan sebagai variabel lokal. Interval koefisien variabel lokal pada model mixed GWR adalah sebagai berikut.

Tabel 3. Interval koefisien persamaan mixed GWR.

\begin{tabular}{ccc}
\hline Variabel & \multicolumn{2}{c}{ Interval koefisien mixed GWR } \\
\cline { 2 - 3 } & Minimum & Maksimum \\
\hline Intercept & $-39,1227$ & 85,2557 \\
Persentase ruang kelas rusak & $-0,0986$ & 0,0995 \\
Rasio siswa per kelas & $-1,0374$ & 0,8376 \\
Nilai Uji Kompetensi Guru & $-0,4859$ & 1,5738
\end{tabular}

Setelah diperoleh koefisien variabel untuk masing-masing 514 kabupaten/kota, dilakukan perbandingan model yang diperoleh antara model regresi linier, GWR, dan mixed GWR.

Tabel 4. Perbandingan model regresi linier, GWR, dan mixed GWR.

\begin{tabular}{cccc}
\hline Kriteria & \multicolumn{3}{c}{ Model } \\
\cline { 2 - 4 } & Regresi linier & GWR & Mixed GWR \\
\hline AIC & 3111,3785 & 2831,7978 & 2825,5843 \\
AICC & 3111,5442 & 2842,8905 & 2838,1994 \\
R-square & 0,6186 & 0,8136 & 0,8181 \\
\hline
\end{tabular}

Berdasarkan kriteria perbandingan pada tabel 4 menunjukkan model mixed GWR yang paling baik dari ketiga model yang dihasilkan. Hal ini ditunjukkan melalui penghitungan nilai AIC dan AICC terkecil untuk model mixed GWR. Selain itu, nilai R-square terbesar juga dimiliki model mixed GWR. Hal ini membuktikan bahwa dari antara ketiga model yang diperoleh, mixed GWR merupakan model yang paling sesuai untuk memodelkan variabel yang memengaruhi capaian belajar di Indonesia pada taahun 2019.

Selanjutnya, dilakukan pengujian ANOVA terhadap model mixed GWR. Hasil pengujian pada tabel 5 menegaskan bahwa pemodelan mixed GWR lebih baik daripada pemodelan regresi linie. Dengan $\mathrm{H}_{0}$ adalah model mixed GWR sama atau tidak lebih baik daripada regresi linier dan nilai $\mathrm{F}_{\text {statistics }}$ lebih besar daripada $\mathrm{F}_{\text {tabel }}$ menyatakan bahwa $\mathrm{H}_{0}$ ditolak, dapat disimpulkan pemodelan mixed GWR lebih baik dibandingkan model regresi linier.

Tabel 5. Tabel pengujian ANOVA mixed GWR.

\begin{tabular}{ccccc}
\hline Sumber variasi & Sum square & $d f$ & Mean square & F-statistics \\
\hline Global residuals & 12509,7820 & 509,0000 & & \\
Mixed GWR improvement & 6542,6863 & 64,9817 & 100,6851 & \\
Mixed GWR residuals & 5967,0957 & 444,0183 & 13,4389 & 7,4921 \\
\hline
\end{tabular}

Sebelum dilakukan analisis lanjutan, melalui hasil pemodelan mixed GWR, dilakukan pengecekan outlier terhadap observasi. Pengecekan outlier dilakukan terhadap nilai Cook's Distance yang memiliki nilai lebih besar dari tiga kali rata-rata (Cook dan Weisberg, 1982). Diperoleh bahwa tidak terdapat nilai Cook's Distance yang lebih besar dari tiga kali rata-rata keseluruhan nilai $(0,1354)$. Hal ini membuktikan bahwa tidak terdapat outlier pada pemodelan mixed GWR.

Selanjutnya, dilakukan pengujian parsial signifikansi untuk variabel lokal pada masing-masing wilayah observasi menggunakan tingkat signifikansi sebesar 5\%. Diperoleh hasil bahwa tidak semua variabel lokal berpengaruh signifikan di setiap wilayah. Terdapat beberapa wilayah yang hanya memiliki 1 atau 2 variabel lokal yang signifikan. Sebaran signifikansi variabel dapat dilihat pada gambar 3 berikut. 


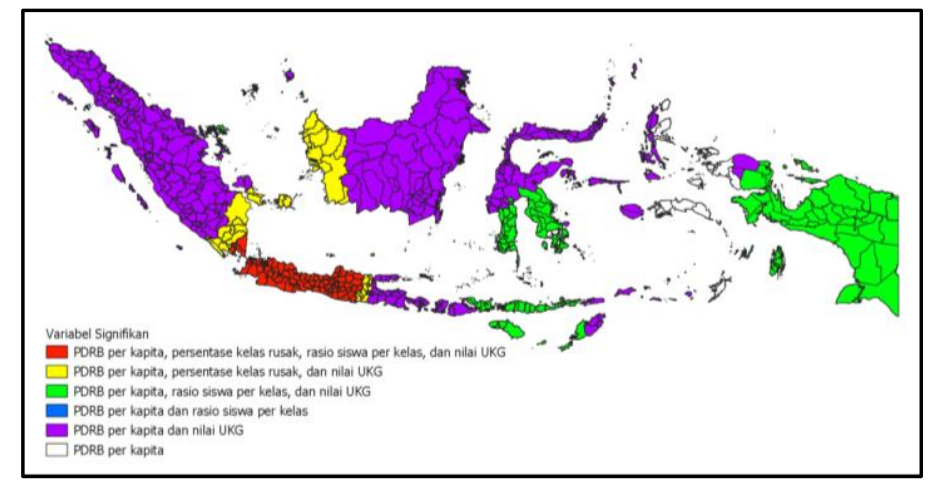

Gambar 3. Peta persebaran kabupaten/kota berdasarkan variabel signifikan yang memengaruhi capaian belajar siswa SMAN, Tahun 2019.

Peta tematik pada gambar 3 menunjukkan pola daerah yang berdekatan cenderung memiliki kesamaan variabel lokal yang memengaruhi capaian belajar. Hal ini dapat diamati melalui kategori yang sama pada wilayah yang berdekatan. Mayoritas kabupaten yang termasuk kategori 1 (berwarna merah) berada di pulau Jawa. Kategori 1 merupakan kabupaten/kota yang memiliki variabel lokal signifikan persentase kelas rusak, rasio siswa per kelas, dan nilai UKG. Selanjutnya, kategori 5 (berwarna ungu) dengan jumlah wilayah terbanyak, mayoritas berada di pulau Sumatera, Kalimantan, dan Sulawesi. Kategori 5 merupakan kabupaten/kota yang memiliki variabel lokal signifikan nilai UKG. Di semua wilayah, variabel PDRB per kapita signifikan karena merupakan variabel global pada model mixed GWR yang terbentuk sebelumnya. Wilayah yang hanya memiliki variabel signifikan berupa variabel global adalah wilayah dengan kategori 6 (berwarna putih). Wilayah yang termasuk kategori 6 yaitu, Kabupaten Maluku Tenggara Barat, Maluku Tengah, Seram Bagian Barat, Seram Bagian Timur, Halmahera Tengah, Halmahera Timur, Pulau Morotai, Sorong Selatan, Sorong, Raja Ampat, dan Kota Sorong.

\section{Determinan Capaian Belajar}

\section{PDRB per Kapita}

Produk Domestik Regional Bruto (PDRB) per kapita merupakan satu-satunya variabel global dalam model persamaan mixed GWR yang dihasilkan pada penelitian ini. Hal ini berarti bahwa koefisien variabel PDRB per kapita bernilai sama di semua wilayah kabupaten/kota. Dengan koefisien 0,0164 dan nilai $p$-value kurang dari 0,05 membuktikan bahwa dengan tingkat kepercayaan 95\%, variabel PDRB per kapita signifikan memengaruhi capaian belajar secara global dan memiliki koefisien yang sama (konstan) di semua wilayah, yaitu sebesar 0,0164.

\section{Persentase Ruang Kelas Rusak}

Berdasarkan gambar 4 kiri atas, variabel persentase ruang kelas rusak berpengaruh signifikan negatif terhadap capaian belajar siswa SMAN di 134 dari 514 kabupaten/kota di Indonesia. Hal ini berarti bahwa semakin tinggi persentase ruang kelas rusak di suatu wilayah kabupaten/kota akan mengurangi capaian belajar siswa di wilayah tersebut.

\section{Rasio Siswa per Kelas}

Menurut hasil output koefisien lokal pada gambar 4, koefisien variabel rasio siswa SMA per kelas atau class size memiliki arah yang berbeda. Variabel ini berpengaruh signifikan di 195 dari 514 kabupaten/kota di Indonesia. Dari 195 wilayah kabupaten/kota dengan variabel rasio siswa per kelas yang signifikan, terdapat 4 kabupaten/kota yang memiliki koefisien signifikan dengan arah positif. Empat wilayah tersebut yaitu, Kota Batam, Kota Tanjung Pinang, Kabupaten Bintan, dan Kabupaten Kepulauan Anambas. Keempat wilayah tersebut berada di provinsi Kepulauan Riau. 


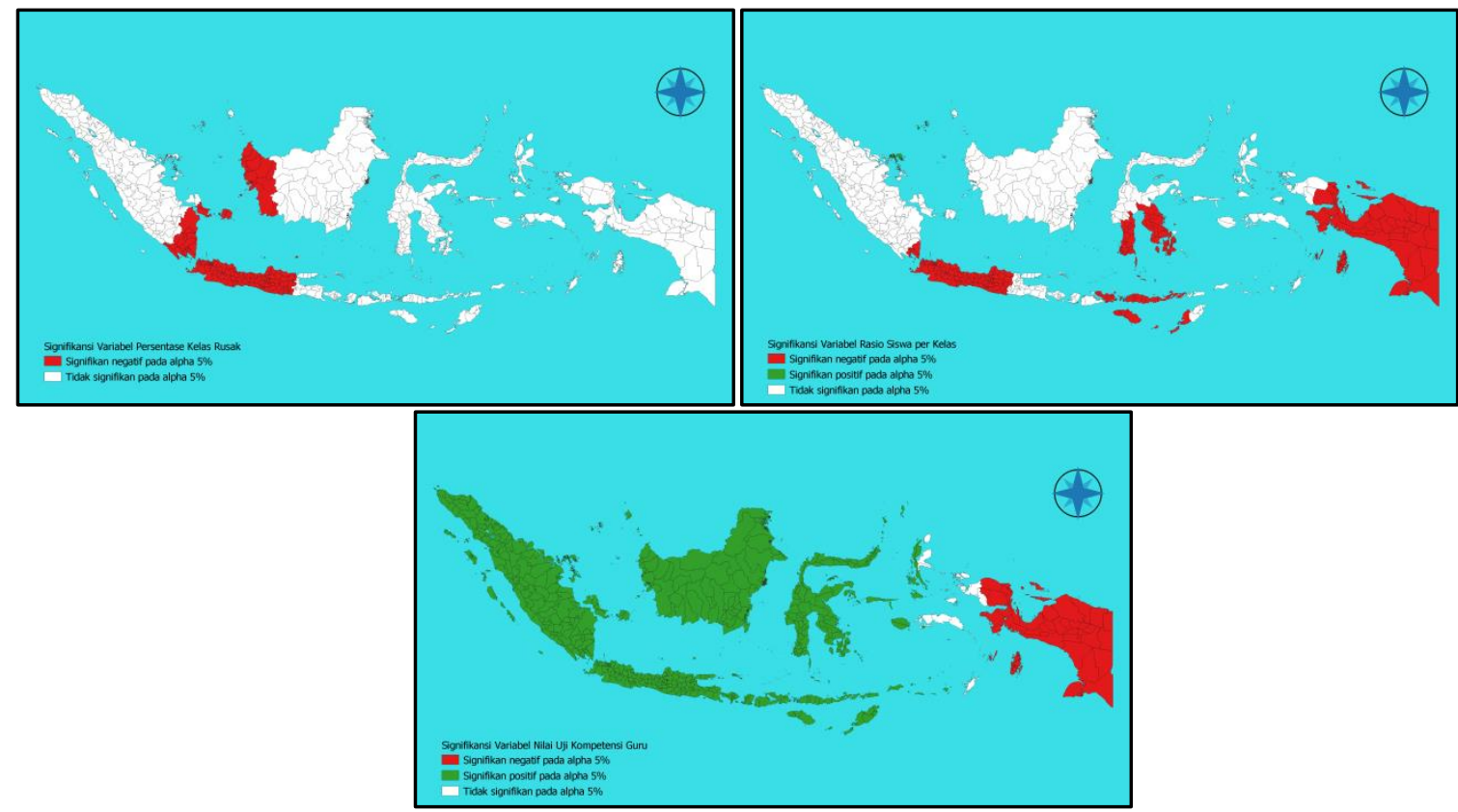

Gambar 4. Peta persebaran signifikansi koefisien variabel lokal: persentase ruang kelas rusak (kiri atas), rasio siwa per kelas (kanan atas), dan nilai Uji Kompetensi Guru (bawah).

\section{Nilai Uji Kompetensi Guru}

Menurut sebaran koefisien lokal pada gambar 4, variabel nilai UKG berpengaruh signifikan terhadap capaian belajar pada 502 kabupaten/kota di Indonesia. Sebaran koefisien variabel nilai UKG tidak memiliki tanda yang sama di semua wilayah. Gambar 4 juga menunjukkan terdapat kecenderungan pengelompokan wilayah kabupaten/kota dengan kategori koefisien nilai UKG yang sama. Pengelompokkan terlihat di kabupaten/kota yang berada di pulau Sumatera, Jawa, dan Sulawesi yang memiliki koefisien signifikan positif. Sementara, kabupaten/kota yang berada di pulau Papua mayoritas memiliki arah koefisien signifikan negatif.

\section{KESIMPULAN}

Kesimpulan yang dapat diperoleh melalui penelitian ini yaitu: pertama, nilai UN sebagai gambaran capaian belajar siswa SMAN tiap kabupaten/kota pada tahun 2019 tersebar tidak merata dan rendah. Hal ini mencerminkan kualitas pendidikan pendidikan di Indonesia yang masih belum mencapai tujuan pendidikan berkualitas untuk semua; kedua, terdapat efek dependensi dan heterogenitas spasial pada capaian belajar tingkat kabupaten/kota di Indonesia; tiga, variabel yang memengaruhi capaian belajar siswa secara bervariasi di tiap wilayah yaitu persentase ruang kelas rusak, rasio siswa per kelas, dan nilai UKG. Sementara, PDRB per kapita berpengaruh secara global (konstan) di semua wilayah. Saran yang dapat diberikan kepada pemerintah untuk membentuk sistem baru yang lebih mampu memetakan kualitas pendidikan dan memperbaiki serta meninjau ulang alokasi sarana prasarana pendidikan di tiap daerah.

\section{UCAPAN TERIMA KASIH}

Terima kasih kepada orangtua, keluarga, dan rekan-rekan penulis yang selalu memberikan dukungan dalam berbagai bentuk di setiap tahapan penelitian ini.

\section{DAFTAR PUSTAKA}

Azwar, S. (2015). Ujian Nasional Sebagai Cermin Mutu Pendidikan dan Pemersatu Bangsa. Jurnal Pendidikan dan Kebudayaan, 21(2), 101-113.

Cook,R., \& Weisberg, S. (1982). Residuals and Influence in Regression.New York: Chapman and Hall.

Fotheringham, A., Brunsdon, C., \& Charlton, M. (2002). Geographically Weighted Regression. West Sussex, 
England: John Wiley \& Sons Ltd.

Freedman, D. A. (2009). Statistical Models: Theory and Practice. Cambridge, United Kingdom: Cambridge University Press.

Neter, J., Wasserman, W., \& Kutner, M. (1989). Applied Linear Regression Models (2nd ed.). Boston, United States of America: RICHARD D. IRWIN, INC.

Peraturan Menteri Pendidikan dan Kebudayaan Republik Indonesia (2019). Penyelenggaraan Ujian yang Diselenggarakan Satuan Pendidikan dan Ujian Nasional. Permendkbud Nomor: 43 Tahun 2019. Kementerian Pendidikan dan Kebudayaan Republik Indonesia. Jakarta.

RI (Republik Indonesia). (2003). Undang-Undang Nomor 20 Tahun 2003 Tentang Sistem Pendidikan Nasional. Sekretariat Negara. Jakarta.

Winkel. (1984). Psikologi Pendidikan dan Evaluasi Belajar. Jakarta: PT. Gramedia. 